Research, part of a Special Feature on Navigating Trade-offs: Working for Conservation and Development Outcomes

\title{
The Principles of Conservation and Development: Do They Apply in Malinau?
}

\author{
$\underline{\text { A K. Boedhihartono }}^{1}, \underline{\text { Petrus Gunarso }}^{2}, \underline{\text { Patrice Levang }}^{2}$, and $^{\text {Jeff Sayer }}{ }^{1}$
}

\begin{abstract}
Attempts to reconcile economic development with environmental conservation in a forest area in East Kalimantan, Indonesia, are reviewed for the district of Malinau, East Kalimantan, Indonesia, an area of $42,000 \mathrm{~km}^{2}$ that is still largely covered in rainforest. The history of the region is described and the conservation and development impacts of external drivers of change are assessed. Both government and conservation organizations have subscribed to the rhetoric of pursuing development pathways that would be sustainable and would conserve the rich biodiversity of the area. Three distinct approaches to conservation have been attempted. First spatial planning has been used to attribute land to different uses and particularly to identify and designate protected areas. Second, measures have been taken to lessen the negative environmental impact of industrial logging and to promote the preservation of biodiversity in logged forests. Last, decentralized and community-based management has been promoted on the assumption that this would yield better environmental and social outcomes than large-scale industrial development. These conservation measures have been pursued during a period when the governance of the region has been weak. Corruption, political collusion, and nepotism have been major factors in decision making about natural resources. We argue that a sustainable future for the district of Malinau must lie in finding an appropriate balance between protected areas, forests managed at both industrial and community scales, and land conversion. However, there is little empirical evidence that allows the outcomes of these approaches to be measured. The problem of knowing how conservation investments can be made in ways that optimize sustainable benefits to local livelihoods remains largely unresolved. A number of possible conservation and development pathways for the district are discussed.
\end{abstract}

Key Words: East Kalimantan; forest dependent peoples; forest-based livelihoods; Indonesia; landscapescale conservation; sustainable forest landscape management.

\section{INTRODUCTION}

The Kabupaten, or District, of Malinau came into existence in 1999 when the larger District of Bulungan was subdivided. Background information on the political, social economic, and environmental features of the District is presented in detail in CIFOR (2002). The District is an administrative unit with an area of about $42,000 \mathrm{~km}^{2}$ and, in 2002 , a population of 37,500 people, about half of whom lived in the capital town, Malinau. The majority of the District area is forested. About $30 \%$ of the total area, in the remote west of the District, is within the Kayan Mentarang National Park. Most of the forests in the other $70 \%$ are allocated to logging concessions with the exception of areas designated as protected forests on steep slopes. Only a very small area is under permanent agriculture although swidden agriculture is practiced by the local communities within the forests (CIFOR 2002). Malinau is the largest and most forested district in Kalimantan. Its forests are recognized as having global conservation value (Sayer et al. 2000, WWF 2007). Internationally and nationally there has been much rhetoric about the desirability of finding development pathways for such areas that reconcile conservation objectives with economic growth and improvements in local livelihoods. Several versions of national plans and programmes dating back to at least the 1980s have expressed Indonesia's intention to pursue pathways of sustainable development (Departemen Kehutanan 1985). The international 
community has supported Indonesian government efforts to achieve sustainable forest management. The European Commission and the Ministry of Forestry (2006) reported that over $\$ 1$ X $10^{9}$ had been spent on forestry projects, most aiming to conserve resources and achieve sustainability, over the past two decades, and the forests have continued to be mismanaged and lost. This ambition to reconcile conservation and development is echoed at a local level, for instance by commitment of the Bupati, the chief administrator of the District, to develop Malinau as a "Green District" (Statements on the WWF-Indonesia website accessed in January 2007 (http://worldwildlife.org/news).

The purpose of this paper is to review the extent to which economic and social developments in Malinau have in reality been linked with, or consistent with natural resource conservation. We also explore ways in which these links might have been made more effectively and suggest options for development pathways that might better reconcile conservation and development. We suggest that historically there have been four major sources of outside influence on conservation and development pathways. These have been measures to promote spatial land-use planning conducted mostly by the central government but also supported by conservation organizations that have sought to identify forest areas of high value for biodiversity (RePPProT 1990 and www.panda.org 29 December 2006). This process was well advance in the 1980s and the distribution of forests already designated for conservation at that time is given in Collins et al. 1991. Second, entrepreneurship and freewheeling capitalism in which high-level government officials and business leaders have colluded in major natural resource exploitation projects (Shin 1989, Aditjondro 1998). Third, efforts to exert influence on industrial logging operators to encourage them to practice environmentally and socially sustainable forestry (Sist et al. 2003, Meijaard et al. 2005). Fourth, decentralization of authority over natural resources to the district and community levels has been encouraged. Decentralization was promoted because local resource managers would have a direct interest in ensuring that development would not degrade the resource base and that it would favor more equitable distribution of benefits (Colfer et al. 1997).

In 1995 the Center for International Forestry Research (CIFOR), an international research and development institute based in Indonesia, signed an agreement with the Government of Indonesia to conduct long-term research on land use and environmental change, sustainable forest management and local livelihoods in the Malinau area (Sayer and Campbell 2004). The rationale for the choice of this area for CIFOR's work was that the area had high environmental values, a significant population of poor, forest-dependent people, and that it was located at the forest frontier. Thus, it was likely to be subject to major developmental impacts over a relatively short period, and it therefore provided an opportunity for CIFOR to contribute to broader understanding of developmental impacts on remote forest areas. The full rationale is further explained in CIFOR's Strategic Plan (http://www.cifor.cgiar. org/AboutCIFOR/VisionMission/Strategy/), Sayer and Campbell (2004) and in the final report of a major collaborative project with the International Tropical Timber Organisation, which attempted to promote the area as a model forest (CIFOR 2002).

This paper seeks to explore the hypothesis that an optimal development pathway will exist that will be based upon a balance between protecting sites of significant biodiversity value, sustainably managing industrial forest resources, allocating areas of forest to local management and conversion of forests to industrial scale agricultural and estate crop uses. The area might therefore become a model of the dominant "protect, manage, and restore" forest conservation paradigm promoted globally by WWF (Sayer et al. 2003). The paper, therefore, seeks to contribute to the discussion of which development pathways might achieve the optimal balance of outcomes to meet the biodiversity objectives of global environmental interest groups and the developmental objectives of poor local communities.

\section{THE HISTORICAL CONTEXT}

Borneo has been inhabited by humans for at least 40,000 yr (Harrison 1959, MacKinnon et al. 1996). The original proto-Malay population has been augmented periodically by major immigrations from other islands and the Asian mainland (Padoch and Peluso 1996). Mining and trade in forest products have had major impacts on settlement patterns and power structures for several centuries. Maritime trade in forest products with India and China was already significant 2000 yr ago (various authors quoted in Padoch and Peluso 1996). There is evidence that the population in the interior of Borneo has been higher in historical times than it 
has been in the recent past. There are abundant signs of old village sites in remote areas that are no longer inhabited and there are documented accounts of major epidemics that drastically reduced the indigenous population in past centuries (Brookfield et al. 1995, Padoch 1985, Nieuwenhuis 1929). The Dutch administration had impacts on population patterns and economic activities during the colonial period.

Historically a sparse population of the different ethnic groups collectively referred to by outsiders as Dayak has practiced swidden agriculture and collected nontimber forest products. In remoter parts of the District such activities continue to provide the livelihoods of local people. Traders located in small towns on the lower reaches of the rivers still purchase products such as bird nests for soup and eaglewood or gaharu, a fragrant wood used as incense and exported to the Middle East and Asia. The slash and burn agriculture practiced by the Dayaks has little impact on the vast expanses of forest although it does create patchworks of different successional vegetation types (Boedhihartono 2004). Until the 1960s development activities were limited to some attempts by the central government and missionaries to provide education and healthcare. Resettlement of people from the densely populated islands of Java and Bali to sparsely populated areas in Kalimantan, known as the transmigration programme, brought settlers to accessible coastal areas but had little impact in Malinau.

During the 1960s, Indonesia was gripped by the "Communist emergency." The wars in Vietnam and Korea and the struggles for power between supporters of the leftward leaning Soekarno regime and the more market oriented Soeharto regime that replaced it in 1965 led to anti-communist campaigns that affected Kalimantan. At the same time the Jakarta government was embroiled in territorial disputes with the Malaysian state of Sarawak. The Dayak in their remote settlements and with their ethnic links with Malaysian Dayaks were caught in the middle of this struggle. Their traditional way of living in communal longhouses was seen as indicating communist tendencies. The Indonesian military became active in the Malinau area, and the government initiated measures to resettle the Dayaks in locations that were more accessible and easier to administer. This resettlement was largely voluntary. People were encouraged to move to villages with improved housing, concrete pathways, schools, and Puskesmas, i.e., dispensaries. As part of the campaign against communism, people were obliged to declare their adherence to one of the five religions officially recognized by the Soeharto "New Order" government. The traditional beliefs of the Dayaks did not conform to the Soeharto orthodoxy. Dayaks therefore declared themselves as belonging to one of the established religions and many opted for Christianity.

Development pressures began to build from the early 1970s. The availability of tracked vehicles and mobile chain saws, and the expanding demand for tropical timber from the rapidly growing economies of Eastern Asia, Europe. and North America led to the logging boom that has continued ever since. Logging concessions became active around Malinau in the 1980s and gradually expanded into the upper Malinau River basin. The logging companies established roads and this had an impact on the distribution of Dayak communities, making it much easier for them to trade the products that they hunted and gathered in the forests. It also enabled them to move around and seek employment with the logging companies.

Spontaneous migration began to be a more significant force in the region at this time. In addition resettlement villages for people from remote areas were established around Malinau town and along the lower reaches of the Malinau and Sesayap Rivers. A small transmigrant village was also established on the outskirts of the town of Malinau. Most migrants, both spontaneous or government sponsored, subsequently moved to the towns in which they became integrated into the local economy as small traders, market gardeners, etc. Others sought work with the logging companies or in sawmills. The population of the Malinau area began to grow rapidly, and the level of economic activity increased.

By the late 1970s the processes of government-led development were well underway in Malinau. The population was concentrated along rivers; children were being educated in the official national language of Bahasa Indonesia. Migrants, civil servants, and logging company employees were an increasing proportion of the population, and the central government was actively planning the future development of the region. The planning included detailed land capability mapping, which was intended to provide a basis for future settlement patterns. Areas suitable for agriculture and tree 
crops were identified and mapped, and locations were selected for villages. Areas not suitable for agriculture were allocated for production forestry. The Ministry of Forestry embarked upon the process of dividing the production forests into concessions and establishing a regulatory framework for their sustainable management. This process also provided for the identification of environmentally sensitive areas, notably steep slopes, and these were set aside as protection forests, i.e., hutan lindung.

Also at this time surveys of wildlife were carried out to identify potential protected areas. As a result of these surveys Kayan Mentarang National Park was gazetted as a nature reserve in 1980 and subsequently as a national park in 1996. This national park covers $1.35 \times 10^{6}$ ha of which 900,000 ha fall within Malinau District. The national park was planned during a period when the conventional wisdom of conservation biology was that protected areas should be as large as possible. However, there are few large, wide-ranging animals in the Malinau area. The forests are species rich but mainly in plants and smaller more localized animal species. One might argue that the interests of conservation might be better served by a finer grained protected area system with a larger number of smaller reserves located in a matrix of managed forest (Zuidema et al. 1997). Kayan Mentarang is a spectacular wilderness, but it does not include all of the habitats that occur in Malinau District. Some interesting wildlife species occur, for instance, in riverine and coastal forests, and these are not protected.

The logic of integration of conservation and development is often based on approaches to conservation that create employment or provide other local benefits (www.panda.org and http://wor ldwildlife.org/news). Plans for the Kayan Mentarang National Park include provision for ecotourism, but the remoteness of the area and the absence of any easily observable wildlife have meant that very few tourists have ever reached the area. It is hard to imagine that ecotourism could generate significant revenues; however, the number of people in the area of the park is so few that even a modest flow of tourists would make a significant contribution to local incomes. Regulations allow the local people to continue some hunting and gathering activities in the park, and in this sense the park will continue to contribute to local incomes but to a lesser extent than it did before conservation programs were initiated.
Kayan Mentarang National Park is one of the world's larger rainforest protected areas. It is recognized as having outstanding biodiversity values, but the enabling legislation is of special interest in the context of this paper as it includes provision for the continued access to, and use of the area, by local Dayak communities. Kayan Mentarang National Park is a core element of the Tri-national "Heart of Borneo" initiative promoted by WWF and supported by the governments of Malaysia, Indonesia, and Brunei. Extensive information on the biodiversity values of this area and the threats to which they are subject is given on the web sites of WWF-International and WWFIndonesia (www.panda.org and http://worldwildlife. org/news).

\section{THE IMPACT OF INDUSTRIAL LOGGING AND MINING}

Industrial logging began in East Kalimantan in the 1960s but only penetrated to the West of Malinau town in the 1980s. Coal mining began in the area close to the village of Long Loreh, about $40 \mathrm{~km}$ from Malinau town in the mid-1990s. Local people welcomed the improved access that logging and mining roads provided and were eager for employment. But already at that time local people complained that they were not offered jobs by the companies, the latter preferring to employ migrants from Sulawesi, Sumatra, and Java. The companies in turn protested that the local people lacked the skills and work discipline needed to fulfill these jobs (Boedhihartono 2004, 2007). This situation changed after the fall of Soeharto in 1998. Relations between the local populations and the logging companies became more difficult when tensions began to arise in relation to traditional land rights. These were exacerbated by social tensions between the indigenous Dayaks and the labour brought in by the companies from other Indonesian islands. International activists joined forces with the Dayaks and the conflicts between them and the logging companies became an international environmental issue

From the early 1990s, the social and environmental sustainability of industrial forestry became a major preoccupation of Indonesia's international development assistance partners. Efforts to create regulatory conditions and provide technical skills to ensure that logging would be sustainable were greatly intensified. Programs to delimit and manage 
protected areas received significant international support. Sophisticated forestry regulations were developed and several development assistance agencies supported projects to promote the implementation of the new regulations.

The Ministry of Forestry, with the assistance of a number of international organizations invested heavily in promoting more sustainable logging practices, and thus, conserving the environmental values of the production forests. The Center for International Forestry Research led work to develop reduced impact logging techniques appropriate for the forests of the area (Sist et al. 2003). Meijaard et al (2005) have reviewed the impacts on wildlife of logging in the Malinau area and concluded that, when logging is conducted carefully, the impact on wildlife is relatively minor. Meijaard and his coworkers make a strong case for the value of loggedover forests for biodiversity conservation.

The 1990s were a period of unprecedented economic growth in Southeast Asia, and this created demand for resources that drove the expansion of the Indonesian economy throughout the decade. A relatively small number of entrepreneurs became extraordinarily influential in allocating forest concession rights.

In other parts of Indonesia this period saw largescale clearance of forests for agriculture and estate crops, the destruction of many areas of natural habitat of high conservation value, and in some locations the emergence of serious social tensions. This was not the case in Malinau. Access to most of the area remained difficult because of the mountainous terrain. The population density was so low that the level of economic activity, other than logging, away from the main rivers and roads was negligible. The density of commercial timber trees was low and logging did not damage the forest excessively (Sayer and Whitmore 1991, Meijaard et al. 2005). Even coal mining only had localized impacts on the environment. The area that had been identified as having high conservation value, Kayan Mentarang National Park, was in the remote mountains and did not come under development pressure. Such social tensions as did occur were more related to jealousies between local workers and immigrants from other Indonesian islands.

There is a widespread perception that the indigenous Dayak communities were the losers in this development process. This view has been effectively communicated through the media and at international environmental meetings by activist groups such as the World Rainforest Movement who effectively lobbied for the rights of Dayak communities in Borneo through their work in Sarawak (WRM 1990). However, on balance the evidence available suggests that most of the indigenous population considered that they benefited from the development that occurred in the 1990s (Boedhihartono 2004, Levang et al. 2007). A proportion of the population obtained work in logging concessions and mines but many people benefited from the indirect advantages linked to the opening up of roads in the area and access to new markets and other facilities. This enabled a significant proportion of the population to increase their material standard of living. Their villages became more accessible and educational and health facilities were improved. People built durable houses; purchased boat engines, small electric generators, televisions, chain saws, and other goods that enhanced their quality of life. A detailed study of some of the most remote and economically marginalized people, i.e., the Punans in the Tubu Basin, showed that the most desired option for many younger people was to leave their villages and seek employment in logging, mining, oil palm plantations, and sawmills both in Indonesia and in Malaysia (Boedhihartono 2004, Levang et al. 2005). Most parents in this study, when questioned about their preferred options for their children indicated that salaried employment was their highest priority. They ranked the options in order of preference as (1) Government employment, teaching, or nursing; (2) military; and (3) missionary work. Manual work in mines or logging concessions was also considered preferable to the traditional activities of hunting and gathering or swidden agriculture (Boedhihartono 2004, 2007).

\section{THE DECENTRALIZATION OF FOREST MANAGEMENT}

The creation of the District of Malinau in 1999 heralded a new period of greater local control over natural resources. The head of the District, the Bupati, is now elected by an assembly of local representatives and since 2004 by universal suffrage. He plays a leading role in governing the District. Many outside observers and several of CIFOR's scientists working in the area had long advocated greater local control of forest management. CIFOR therefore invested considerable 
resources in studying the impacts of decentralization in the Malinau area (Limberg 2005, Samsu et al. 2005, Barr et al. 2006). A higher proportion of the rents from resource extracting industries are now retained by the local administration. The allocation of logging concessions, their management, and the collection of royalties is now under the control of the district administration. The same applies to mineral exploration and extraction rights. The District now has its own resources for constructing roads, bridges, and social infrastructure. The level of prosperity in the region has risen significantly although statistics to document this are lacking. However, house and land prices are increasing, new buildings are being constructed and traffic jams are occurring for the first time ever in Malinau town.

Local communities have been given the right to manage logging in small areas of forests adjacent to their villages. This system, known Izin Pemungutan dan Pemanfaatan Kayu (IPPK), i.e., the right to exploit and use timber, is reviewed in Sayer and Campbell (2004). In many cases villagers sold these rights to outside investors who have probably logged in more destructive ways than the larger Indonesian concession holders who preceded them. The reality was that although this system did enable the local communities to obtain short-term revenues directly from logging it did little to encourage longer-term sustainability. In addition the businessmen often failed to make the agreed payments. The IPPK system has now been replaced by another type of small-scale concession, the Ijin Usaha Pemanfaatan Hasil Hutan Kayu (IUPHHK), i.e., permit to use forest products and timber.

Under this decentralized governance, there has been a dramatic improvement in the infrastructure in and around the District capital of Kota Malinau. Schools, hospitals, roads, and bridges have been constructed. Far more goods and services are available and the town has grown from a small isolated backwater to a booming frontier town. It is less clear what the impact of decentralization has been in the remoter parts of the district. Plans are being developed to open up new roads into very remote areas. Such initiatives are almost universally welcomed by local people. Improved road access is always their first priority in any discussion of development (Boedhihartono 2004). It is inevitable that these new roads will result in more logging in remote areas and there is little evidence of any local capacity to regulate this process and ensue that good forestry practices are adopted.
Now that much decision making is in local hands, questions are being asked about the role of protected areas. It has been pointed out to us by the Bupati himself that protected areas make up $30 \%$ of the land area of the District but contribute almost nothing to its revenues. The protected areas are almost never visited by anyone apart from conservationists conducting surveys and preparing plans. Up until now there has been plenty of forest land available for any new enterprises and the Bupati has been sympathetic to conservation aims. In fact he has cultivated strong links with conservation organizations and would like his District to be known as a "Green District." But as pressures for development grow and as he faces reelection, the pressures of local economic interests will increase and the costs of having a large area of land off-limits to meet hypothetical national or global level conservation needs will be a source of local resistance. A number of plans for major investments in oil palm development have recently been announced and although none have yet proceeded to implementation it seems inevitable that oil palm estates will be a major feature of the future landscapes of the District (Sheil and Basuki 2005).

\section{INVESTMENTS IN DEVELOPMENT IN MALINAU}

There have been very considerable investments in providing social infrastructure throughout the District but especially in the more accessible areas. Most people probably consider that their livelihoods have improved significantly over the past 2-3 decades. The most significant contributions to economic and social development have certainly come from the money that flowed into the region as a result of commercial activities. Logging, mining, and to a lesser extent plantation establishment have all created jobs and put money into the local economy. None of this money has directly targeted conservation objectives. Conservation was not a significant part of the development agenda and was certainly not an objective of commercial investments. Economic activity certainly had an impact on conservation. It probably increased pressure on the forests by providing expanded markets for products derived from hunting and gathering. It may have lessened the pressure on the forest from shifting agriculture as, given the choice; people prefer the paid employment in mines and forestry to labour in subsistence agriculture 
(Boedhihartono 2004). However, it is also possible that the influx of people from other parts of Indonesia seeking employment may have produced some pressure for land clearing for agriculture. The fact that people used their earning to buy chainsaws and boat engines is thought by many people to increase the pressure on the forests, but there is no empirical data to support this suggestion. The tendency of people to concentrate in the more accessible parts of the District and around areas in which extractive industries are active may have reduced population density and pressure on the forests in remoter areas.

There has been no deliberate attempt to use development investments to achieve specific conservation goals in the area. There is little evidence of the impact of development on conservation. However, it seems likely that development has led to increased pressure on forests in accessible areas and to reduced pressure in remote, inaccessible areas.

\section{SPATIAL PLANS}

Spatial plans have been developed at a coarse scale for the region by the provincial planning agency, the Badan Perencanaan dan Pembangunan Daerah or BAPPEDA. Land use plans are based largely on biophysical criteria. Areas of steep slopes have been designated as protected forests (hutan lindung) and the Kayan Mentarang National Park has been legally established, albeit with provision for a degree of local use. The rest of the area has been allocated to forest concessions with a few small areas designated for agriculture and estate crops. Wollenberg et al. (2007) have discussed the issues of local influence on, or involvement in, spatial planning in the District. There has been little concern for social considerations or customary or adat rights. Adat refers to the body of customary but often unwritten law that has historically regulated many aspects of Indonesian life and whose legitimacy is enshrined in the Indonesian constitution. Surprisingly, given that a number of conservation organizations have been active in the area for two decades there is little information on the relative biodiversity importance of different areas of forest either inside or outside the national park. One might expect that areas of forest on different geological substrates, on isolated mountains or in coastal or riverine habitats would have special features of conservation concern. In spite of considerable efforts invested in biological surveys we still have insufficient knowledge of the patterns of distribution of plant and animal species in the forests of Malinau. Sheil et al. (2003) have conducted surveys in which they have contrasted the value of biodiversity and forests from the perspectives of local people and of external taxonomists. This work showed that local people attach values to natural habitats and to certain species of plants and animals. Local people's values are instrumental, they relate to the utility of the habitat or species. Conservationists and taxonomists value the existence of species irrespective of their utility. These studies served to further emphasize the difficulty of applying concepts such as that of high conservation value forests to extensive areas of contiguous forests such as those found in the Malinau area. Whose values should prevail and on the basis of whose criteria should one area of forest be considered of higher value than another (Padmanaba and Sheil 2007, Sheil et al. 2006)?

Eventually, more detailed information will become available on the patterns of biodiversity in the area and on the relative potential of different areas for different crops. This might allow the establishment of a much finer grained spatial plan to identify small areas of special habitats, which might be established as nature reserves, or subject to special management arrangements. However, the rate of expansion of estate crops might be so rapid that valuable areas of forest could be destroyed before they have been properly surveyed.

\section{INTEGRATED CONSERVATION AND DEVELOPMENT PROGRAMS}

The underlying assumptions governing the integrated conservation and development programs (ICDP) approach are discussed in Garnett et al. (2007). The classic approach to an ICDP in an area such as Malinau would consist of a series of local development initiatives to improve the livelihoods of people living adjacent to the Kayan Mentarang National Park (McShane and Wells 2004). In reality some income generating activities were included in the plans prepared for the national park but none were ever implemented except on a very small and informal scale. There has been talk of locally operated ecotourism but it has not yet proved possible to attract many tourists. Small contributions have been made of generators and water pumps to villages along the Upper Bahau 
River where it borders the park, but these have not been on a scale to influence people's livelihoods in any significant way. The prosperity of these villages has increased in recent years but mostly as a result of money remitted from employment either in Indonesian logging concessions or from people who have gone to work in the Malaysian State of Sarawak. In the event that more visitors do come to the park in the future then there might be potential for villagers in remote areas to augment their incomes from activities related to nature-based tourism.

\section{PROTECTED AREAS LINKED TO PRODUCTION FORESTS}

Indonesian law requires that areas of around 300 ha be set aside within industrial logging concessions as seed stands. A number of studies have shown that these areas may have broad conservation value (Johns 1992). This is especially so when the forest as a whole is managed in ways that favor the retention of biodiversity (Sheil et al. 2005). The laws governing industrial plantations require that $30 \%$ of the area be retained under natural forest for conservation purposes. Unfortunately this law is not rigorously applied. Such islands of natural forest, located within an estate that is under proper management, and where protection could benefit from the infrastructure and resources of the plantation company, could make valuable contributions to conservation. Residual natural areas, within both logged natural forests and timber estates, do have conservation value (Sheil et al. 2005), but little is know about them, they are not monitored, and little is done to secure their longterm security. Zuidema et al. (1997) have argued for the importance of small and intermediate sized conservation areas such as these within a landscapescale matrix of managed forests and other landcover types. A landscape composed of small reserves set within a matrix of sustainably managed forest will be less susceptible to the loss of species resulting from habitat fragmentation than when the reserves are isolated within extensive non-forest land. There is considerable potential for the establishment of such a habitat matrices in East Kalimantan.

Measures to improve the management of logging in natural forests have yielded significant biodiversity benefits (Sheil et al. 2005). However, little is known about the range of species that are effectively protected in these systems and the long-term security of the forests after the first cutting cycle remains in doubt. The large-scale logging concessions in the area are potentially important resources for conservation as long as they are well managed. The only caveat is that external threats such as climate change may make logged forests more susceptible to fire. Conversion to estate crops, e.g., oil palm etc., is a threat in the long-term but it seems improbable that such plantations would be established over a significant part of the remoter areas of the District. However there are indications that companies whose core business is logging may seek permission for the establishment of palm oil estates as a pretext for getting access to the timber on the land.

\section{COMMUNITY CONTROL OF FORESTS}

It had been widely believed that the reinstatement of traditional rights, and a shift towards more local control of forest management would lead to better and more sustainable management of logging and more capture of nontimber values of forests for local people. The brief experience with the Izin Pemungutan dan Pemanfaatan Kayu (IPPK) concept in the late 1990s showed some of the dangers of this approach. The problem is that industrial logging requires a lot of capital, and a critical mass of lumber is required to make sawmills and transport infrastructure affordable. Schemes that local people can manage jointly with industrial concessionaires might have more potential but little progress has been made in developing such schemes. Most community involvement has been focused on negotiations with logging companies or with the District authorities to limit the damage to local resources that results from inappropriate logging. The situation is further complicated when some people from indigenous communities negotiate directly with logging companies to "do deals" for logging of forests under local land claims. A Merap lawyer originally from the Malinau Basin but who has lived in Java for many years has reportedly been attempting to negotiate such deals with outside logging companies. These sorts of deals result in some local families getting very rich whilst others receive few benefits.

A number of communities have recently shown an interest in conserving their forests. To some extent this has been prompted by the publicity in the local media of a CIFOR initiative to establish environmental service payments in Setulang 
village. The 26 families in this community, located close to Malinau town, sought support from CIFOR in the protection of their forest. Their motivation apparently was that they believed that they could get future income from nontimber forest products and even from recreational use by inhabitants of the future city of Malinau. Another nearby group, the Tidung of Golong Solok wanted to conserve 20,000 ha of forest in a karst area surrounding caves in which they had traditionally harvested bird nests. None of these initiatives have yet progressed to the stage at which they could be said to be sustainable but the fact that interest is being shown suggests that they may have some potential to reconcile local needs with the imperatives of industrial logging.

\section{Indigenous reserves: locally managed multiple- use areas}

The concept of indigenous or extractive reserves that has both reduced deforestation and contributed to improved local livelihoods in some Latin America countries could potentially be appropriate for the Malinau area. The rules under which Kayan Mentarang National Park was finally established gave considerable rights to land and forest products to the local population. In some ways several of Indonesia's National Parks are closer to the multiple-use categories V and VI of IUCN than they are to the category I-III of totally protected areas. They therefore have a status similar to the indigenous reserves and extractive reserves in the Amazon. The local population throughout the remoter parts of the Malinau District are already making extensive use of nontimber forest products and are hunting for their subsistence needs and this does not in general appear to pose serious conservation threats. However, the demand for bezoar stones, i.e., gall stones from sun bears and primates, for traditional Chinese medicine in some remote areas in the Apo Kayan region to the southeast of Malinau District has led to massive killing of leaf monkeys sponsored by Chinese traders. Giving exclusive rights to these products to the local population in exchange for guarantees that the forest would be maintained might provide a viable conservation compromise. There has been some discussion about giving the Tubu catchment the status of an "indigenous reserve" but the legislative basis for this is not yet adequate in Indonesia. There is no reason why selective logging for high value species should not be allowed in such an indigenous or extractive reserve.

\section{Payments for environmental services}

Environmental service payments are being explored as a mechanism to conserve the global environmental values of tropical forests. There are very few examples in which this has proceeded beyond a pilot scale in developing countries (Landel-Mills and Porras 2002). Two initiatives in the Malinau area attempted to secure environmental service payments. The first was a trial programme of reduced impact logging (RIL) conducted by CIFOR, the Indonesian Forest Research Agency (FORDA) and the state logging company Inhutani II (Sist et al. 2003). The trials were funded by the New England Electric Power Company in the United States, and were recognized as a carbon sequestration project under the pilot phase of the Clean Development Mechanism of the United Nations Framework Convention on Climate Change [ERRATUM]. The work did show that RIL resulted in higher residual carbon in the forest and a more rapid carbon uptake in post-logging regeneration. The hope had been that loggers would be able to receive a subsidy from companies seeking carbon credits under the Clean Development Mechanism or other systems elaborated to pay for carbon sequestration services, but the long time-lag in getting the Kyoto Protocol adopted and the tight conditions that were eventually applied to carbon sequestration credits has meant that to date no payments have been made in Malinau or elsewhere for carbon sequestered as a result of RIL.

The second attempt at establishing an environmental service payment in Malinau came from the initiative by the village of Setulang. At that time villages were being given rights over small areas of forest to which they had some traditional claims (IPPK). Since villages could not afford the equipment that would have been needed if they were to log these forests themselves most sold the rights to businessmen. Setulang village offered to forgo the offers of logging companies and to conserve their forest in exchange for a financial contribution to offset the lost revenue from not logging the forests. Scientists from CIFOR saw this as an opportunity to get some real practical experience with an environmental service payment scheme. In addition the village was quite accessible and its forests covered a broad ecological gradient and were in good condition. CIFOR, despite its reputation and excellent international networks, was unable to find any sponsor willing to make the environmental payments. 


\section{Villages with a conservation designation}

This is a concept developed by the International Center for Research in Agroforestry (ICRAF) in Krui in South Sumatera and in the Gunung Halimun area in West Java. ICRAF scientists have worked with the people in villages bordering the Bukit Barisan and Gunung Halimun National Parks to seek development benefits linked to conservation programmes. There are some similarities between this approach and the work that CIFOR has attempted in Setulang Village. Many forest sites in Indonesia are protected by local people for cultural and religious reasons, and this local conservation ethic could form a starting point for negotiations on locally relevant protected areas. The UNESCO Man and Biosphere Programme in Indonesia has recently initiated work on this subject but it is too early to say how much impact this might have.

\section{CONCLUSIONS}

A number of Indonesian research institutions and the World Wide Fund for Nature (WWF) have been active in the Malinau area since the mid-1980s. They were primarily concerned with nature conservation and sustainable forest management but were also drawn to the area by interest in the cultures of the forest dependent Dayak peoples that lived in remote parts of the District. CIFOR has conducted studies in the area for over a decade and the basic orientation of much of this work was to seek to manage forest resources in a sustainable way that would contribute to environmental conservation and local peoples' well-being. We now understand much more about how local people use and depend on forests. We also know about the benefits that they obtain from the forests and costs that they incur when forests are managed badly and when other resource industries become established in the area.

Some communities have started to show concern over the degradation of forests. The village of Setulang, the location of CIFOR's attempts to establish a system of environmental service payments, is a good example. Many of the younger male inhabitants of this and other villages now work for logging companies elsewhere, some as far away as Brazil, but they state that they prefer to earn their living exploiting forests elsewhere whilst conserving the forests near to their home.
In spite of all the interest in conservation and development in the area the two processes have largely been pursued in parallel. Conservation and development can only really be said to have been integrated in the case of improved management of production forests in which larger logging companies often hired professional forest managers and observed surprisingly high standards of forest management. Otherwise conservation has made little contribution to development and development has proceeded with little regard for the conservation of forests.

In conclusion the main achievements of conservation programmes in the area have been the legal gazettement of the Kayan Mentarang National Park, the documentation of the fauna and flora of the park and of the activities of the human populations in the area and the raising of public and political awareness of conservation needs. This has not had any significant impact on local livelihoods although employment with conservation organizations to help with surveys etc. has probably been a significant temporary source of income in some remote villages. Attempts to maintain local cultural traditions have been linked to conservation programmes. The rich local culture is clearly of value in its own right but its potential as a resource to attract visitors to the area has also generated interest amongst some local communities. Improvements in logging practices may have brought incidental benefits to local people through improved access to and availability of nontimber forest products and reduced damage to water quality in streams.

CIFOR is in the process of re-evaluating its role in the area and some critics have pointed out that the research that has been conducted up until now has had little practical impact on either livelihood improvement or conservation. In response to this CIFOR has embarked upon research that lies outside its normal core business and is now involved in work on health and nutrition in remote forest areas. An alliance is being formed with the medical NGO Médecins du Monde. WWF is launching a major initiative to conserve extensive forest areas in the "Heart of Borneo" (http://www.panda.org). This aims to retain a landscape of continuous forest composed of networks of protected areas linked by sustainably managed production forests. Pragmatism has forced all of the organizations that originally came to the area to promote conservation to take a 
greater interest in local development activities. Views on what sort of development scenario could best complement conservation objectives are still divergent. There is a need for a genuine debate amongst the different interest groups in the area about what sort of future they would like. At present the institutions and processes that might orchestrate such a debate do not really exist. Some of the models of public debate about sustainable development that have occurred in the post Earth Summit period and the attempts to enable multi-stakeholder groups to negotiate indicators of sustainable development could usefully be applied in Malinau (e.g., the approaches described by Bell and Morse 1999).

Local people welcome outside development investments. They actively seek work in logging and estate crops, mines, and small local enterprises around settlements. There is a continuing tendency to move away from remoter areas and for the population to concentrate in locations where schools, dispensaries, and employment can be found. Local people are not opposed to conservation but see it as something that will provide them with few benefits and may limit their development options. Estate crops and mines generate the highest earning potential for local people, followed by logging and with conservation a distant third. There is abundant rhetoric about conservation but most decisions, at all levels from the household to the central government, are driven by the desire for short-term financial gain.

There are plans to greatly improve the road infrastructure into the remotest parts of the area. One controversial proposal was for the companies constructing the roads to be allowed to harvest and sell timber located within about $1 \mathrm{~km}$ of the new road to pay for construction costs (Sheil et al. 2005). Such major investments could open up the remoter forest areas to more intensive logging and possibly estate crop development. So far such schemes have been vetoed by the central government but they remain a threat.

Conservation programmes have to be set within a vision of what the future of the area might look like. Will Malinau remain a remote frontier area dependent on resource extracting industries? Or will it gradually evolve into the condition found in Peninsular Malaysia where all of the better land is under estate crops or agriculture and conservation areas are restricted to remote, steeply sloping mountains. Will sustainable management of near- natural forests integrated with nature conservation and forest use by local people continue to be the predominant use of land in the area or will this cease to be profitable as industrial plantations expand? What is the role of research in all of this?

In the past few years Malinau has moved from being an isolated and backward region to having one of the highest per capita incomes in the country. This has been partly based on the expansion of extractive industries in the District but also because of payments of a share of oil revenues from other districts in East Kalimantan. However, in spite of over a decade of fairly intense work on forest conservation and development by a number of national and international bodies there is still much uncertainty about what lies ahead. So far most of the natural values of the forests of the area are still intact. The people are rapidly improving their livelihoods.

Perhaps the greatest hope lies in a more intense dialogue between those who are promoting conservation and those who are seeking development. This must occur in Malinau and the role of the District authorities must be to facilitate this process. There must be more learning about the dangers of certain types of development and the pros and cons of different approaches to conservation. Conservationists must not come in with a blueprint for the District but must engage with local processes and "muddle through" (Wollenberg et al. 2007). If the international community seeks conservation outcomes that will limit the development options of local people then they have to be more realistic about what they can offer in exchange for these "global public goods." A good starting point would be a process to allow the population and outside stakeholders to develop indicators of what sustainable development in the area might look like (Bell and Morse 1999). The heart of Borneo is the largest and most important area of tropical rainforest left in Asia and its future should not be left to chance. However, as long as conservation programmes limit the possibilities for local development they will fail. Either compensation must be provided or a conservation approach that has more relevance to local communities must be found (Sheil and Boissière 2006, Sheil et al. 2006, Padmanaba and Sheil 2007). 
Responses to this article can be read online at:

http://www.ecologyandsociety.org/vol12/iss2/art2/responses/

\section{LITERATURE CITED}

Aditjondro, G. J. 1998. Suharto and Sons: crony capitalism, Suharto style. Washington Post, 25 January 1998.

Barr, C., I. A. P. Resosudarmo, A. Dermawan, J. F. McCarthy, M. Moeliono, and B. Setiono. 2006. Decentralization of forest administration in Indonesia: implications for forest sustainability, economic development and community livelihoods. Center for International Forestry Research (CIFOR), Bogor, Indonesia.

Bell S., and S. Morse. 1999. Sustainability indicators: measuring the immeasurable. Earthscan, London, UK.

Boedhihartono, A. K. 2004. Dilemme à Malinau, Borneo: être ou ne pas être un chasseur-cueilleur Punan. Dissertation. University of Paris 7, Paris, France.

Brookfield, H. C., L. Potter, and Y. Byron. 1995. In place of the forest: environmental and socioeconomic transformation in Borneo and the Eastern Malay Peninsula, United Nations University Press, Tokyo, Japan. Available online at: http://www.cifor. cgiar.org/AboutCIFOR/VisionMission/Strategy/.

Center for International Forestry Research (CIFOR). 2002. International Tropical Timber Organization (ITTO) project PD 12/97 Rev.1 (F). Forest, science and sustainability: the Bulungan model forest. Technical Report Phase I, 1997-2001. CIFOR and ITTO, Bogor, Indonesia.

Colfer, C., N. Peluso, and S. C. Chin. 1997. Beyond slash and burn: building on indigenous management of Borneo's tropical rainforests. The New York Botanical Garden, New York, New York, USA.

Collins, N. M., J. A. Sayer, and T. C. Whitmore. 1991. Chapter 19: Indonesia. The conservation atlas of tropical forests: Asia and the Pacific. Simon and Schuster, New York, New York, USA.

Departemen Kehutanan Republik Indonesia.
1985. Draft long-term forestry plan. Jakarta, Indonesia.

European Commission, Jakarta and Ministry of Forestry, Indonesia. 2006. Capitalisation on two decades of development assistance to forestry in Indonesia. Report of a workshop sponsored by the Ministry of Forestry and the European Commission, Jakarta, (March 2006), Jakarta, Indonesia.

Garnett, S. T., J. A. Sayer, and J. du Toit. 2007. Improving the effectiveness of interventions to balance conservation and development: a conceptual framework. Ecology and Society [Online] URL:http://www.ecologyandsociety.org/vol12/ iss1/art2/.

Harrison, T.K, editor. 1959. The peoples of Sarawak. Sarawak Museum, Kuching, Malaysia.

Johns, A. D. 1992. Species conservation in managed tropical forests. In J. A. Sayer and T. C. Whitmore, editors. Realistic strategies for tropical forest conservation. The World Conservation Union (IUCN), Gland, Switzerland.

Landell-Mills, N., and I. T. Porras. 2002. Silver bullet or fools' Gold? A global overview of markets for environmental services and their impact on the poor. IIED, London, UK.

Levang P., E. Dounias, and S. Sitorus. 2005. Out of the forest, out of poverty? Forests, Trees, and Livelihoods 15:211-235.

Levang, P., S. Sitorus, and E. Dounias. 2007. City life in the midst of the forest: a Punan huntergatherer's vision of conservation and development. Ecology and Society [Online] URL:http://www.eco logyandsociety.org/vol12/iss 1/art18/.

Limberg, G., R. Iwan, M. Sudana, A. Hartono, M. Henry, D. Hernawan, D. Sole, Mamung, E. Wollenberg, and M. Moeliono. 2005. Profil desadesa di Kabupaten Malinau: kondisi sosial ekonomi di desa-desa. Center for International Forestry Research (CIFOR), Bogor, Indonesia.

MacKinnon, K., G. Hatta, H. Halim, and A. Mangalik. 1996. The Ecology of Kalimantan; Indonesian Borneo. Periplus Editions, Hong Kong.

McShane, T., and M. Wells. 2004. Getting biodiversity conservation projects to work: towards 
more effective conservation and development. Colombia University Press, New York, New York, USA.

Ministry of Forestry. 2007. Program Kehutanan, Nasional, 2005-2025. Available online at: http://w ww.dephut.go.id/content.php?id=229.

Meijaard, E., D. Sheil, R. Nasi, D. Augeri, B. Rosenbaum, D. Iskander, T. Setyawati, M. Lammertink, I. Rechmatika, A. Wong, T. Soehartono, S. Stanley, and T. O'Brien.2005. Life after logging: reconciling wildlife conservation with production forestry in Indonesian Borneo. Centre for International Forestry Research, Bogor, Indonesia.

Niewenhuis, A. W. 1929. Ten years of hygiene and ethnography in primitive Borneo (1891-1901). Pages 13-33 in B. Schrieke, editor. The effects of western influence on native civilizations in the Malay Archipelago, Batavia, Java.

Padmanaba, M., and D. Sheil. 2007. Finding and promoting a local conservation consensus in a globally important tropical forest landscape. Journal of Biodiversity Conservation 16:(1) 137-151.

Padoch, C. 1985. Labour efficiency and intensity of land use in rice production: an example from Kalimantan. Human Ecology 13(3):271-289.

Padoch, C., and N. Peluso, editors. 1996. Borneo in transition: people, forests, conservation, and development. Oxford University Press, Kuala Lumpur, Malaysia.

Regional Physical Planning Programme for Transmigration (RePPProT). 1990. National overview of the regional physical panning programme for transmigration. Overseas Development Natural Resources Institute, Chatham, UK.

Samsu, Suramenggala I., H. Komarudin, and Y. Ngau. 2005. The impacts of forestry decentralization on district finances, local communities and spatial planning: a case study in Bulungan District, East Kalimantan. Center for International Forestry Research (CIFOR), Bogor, Indonesia. Available online at: http://www.cifor.cgiar.org/publications/ pdf files/Books/Decentralisation-Case12.pdf.

Sayer, J. A., and T. C. Whitmore. 1991. Tropical moist forests: destruction and species extinction. Biological Conservation 55:199-213.

Sayer, J. A., N. Ishwaran, J. Thorsell, and T. Sigatty. 2000. Tropical forest biodiversity and the world heritage convention. Ambio 29(6):302-309.

Sayer J., C. Elliot, and S. Maginnis. 2003. Protect, manage and restore: conserving forests in multifunctional landscapes. Proceedings of the 12th World Forestry Congress, Quebec, Canada.

Sayer, J. A., and B. Campbell. 2004. The science of sustainable development: local livelihoods and the global environment. Cambridge University Press, Cambridge, UK.

Sheil, D., R. K. Puri, I. Basuki, M. van Heist, M. Wan, N. Liswanti, Rukmiyati, M. A. Sardjono, I. Samsoedin, K. Sidiyasa, Chrisandini, E. Permana, E. M. Angi, F. Gatzweiler, B. Johnson, and A. Wijaya. 2003. Exploring biological diversity, environment and local people's perspectives in forest landscapes. Center for International Forestry Research (CIFOR) and the International Tropical Timber Organization (ITTO), Bogor, Indonesia.

Sheil, D. and I. Basuki. 2005. Future rides on land use. The Jakarta Post, 30 March 2005.

Sheil, D., R. Puri, M, Wan, I. Basuki, M. van Heist, N. Liswanti, Rukmiyati, I. Rachmatika, and I. Samsoedin. 2006. Recognising local people's priorities for tropical forest biodiversity. Ambio 35(1)17-24.

Sheil, D. and M. Boissière. 2006. Local people may be the best allies in conservation. Nature $\mathbf{4 4 0}$ (7086):868.

Shin, H. S. 1989. Demystifying the capitalist state: political patronage, bureaucratic interests, and capitalists-in-formation in Soeharto's Indonesia. Dissertation. University of Yale, New Haven, Connecticut, USA.

Sist, P., D. Sheil, K. Kartawinata, and H. Priyadi. 2003. Reduced Impact logging in Indonesian Borneo: some results confirming the need for new silvicultural prescriptions. Forest Ecology and Management 179:415-427.

Wollenburg, E., I. Ramses, G. Limbert, M. 
Moeliono, S. Rhee, and M. Sudana. 2007. Facilitating cooperation during times of chaos: spontaneous orders and muddling through in Malinau District, Indonesia. [Online] URL:http://w ww.ecologyandsociety.org/vol12/iss1/art3/.

\section{World Rainforest Movement and Sahabat Alam} Malaysia (WRM). 1990. The battle for Sarawak's forests. World Rainforest Movement, Montevideo, Uruguay.

World Wildlife Fund (WWF) 2007. Available online at: http://worldwildlife.org/news).

Zuidema, P., J. A. Sayer, and W. Dijkman. 1997. Forest fragmentation and biodiversity: the case for intermediate sized conservation areas. Environmental Conservation 23(4):290-297. 